\title{
ANALISIS MINAT BELAJAR MATEMATIKA SISWA SMP KELAS IX PADA MATERI GRAFIK FUNGSI KUADRAT BERBANTUAN SOFTWARE GEOGEBRA
}

\author{
Siti Sarah Khodijah' ${ }^{1}$, Wahyu Setiawan ${ }^{2}$ \\ ${ }^{I}$ SMP Bingkai Cendikia Cililin, Desa Rancapanggung, Kabupaten Bandung Barat \\ ${ }^{2}$ IKIP Siliwangi, Jl. Terusan Jenderal Sudirman, Cimahi \\ E-mail: sitisarah.khadijah@gmail.com
}

\begin{abstract}
Abstrak
Tujuan dari penelitian ini adalah untuk menganalisis minat siswa dalam pembelajaran matematika pada materi Grafik Fungsi Kuadrat berbantuan software GeoGebra. Dalam penelitian ini, metode yang digunakan adalah penelitian deskriptif, yaitu penelitian yang menghasilkan data deskriptif melalui presentase jawaban siswa yang memuat 5 indikator skala minat belajar siswa pada angket yang diberikan. Populasi dalam penelitian ini yaitu seluruh siswa SMP di Kabupaten Bandung Barat dengan sampel yang digunakan adalah 28 orang siswa kelas IX SMP Bingkai Cendikia Cililin. Pengumpulan data penelitian menggunakan angket skala minat belajar siswa pada pembelajaran matematika berbantuan software GeoGebra yang memuat 20 pernyataan masing-masing 10 pernyataan positif dan negatif. Hasil analisis pada penelitian ini dapat disimpulkan terdapat dampak positif terhadap minat belajar matematika siswa dengan adanya bantuan software GeoGebra. Hal tersebut terlihat dari presentase rata-rata jawaban siswa yang berpendapat sangat setuju pada pernyataan positif sebanyak $49 \%$, kemudian pada respon setuju menghasilkan rata-rata sebesar $67 \%$, untuk respon tidak setuju sebanyak $10,8 \%$, sedangkan untuk respon sangat tidak setuju sebesar 6,5\%.
\end{abstract}

Kata Kunci: Geogebra, Minat Belajar Matematika Siswa, Grafik Fungsi Kuadrat

\begin{abstract}
The purpose of this research's to analyze students interest in mathematical leaning by the matery Grafik Fungsi Kuadrat (Graphs of Quadratic Functions) assisted by GeoGebra sofware. In this research, the researcher used descriptive research method, descriptive research method is the research that generates descriptive data through the percentage of student answers that contain 5 indicators of learning interest scale students by given poll. The population of this research were 28 students of nineth grade of SMP Bingkai Cendikia Cililin. Research data were collected by using the scale of learning interest of students in GeoGebra sofware assisted with mathematics learning that contains 20 questions each 10 positive and negative questions. The result of the data analysis could be concluded that there is a positive impact on students interest in learning mathematics assisted with GeoGebra sofware. The result of the data analysis showed by the average percentage of answers of students who agree of positive statement's $49 \%$, then the response of agree average of $67 \%$, and then disagree response's $10,8 \%$, while for strongly disagreeing responses of $6.5 \%$.
\end{abstract}

Keywords: Geogebra, Student' Interest in Learning Mathematics, Graphs of Quadratic Functions 


\section{PENDAHULUAN}

Matematika adalah salah satu ilmu yang dipelajari peserta didik mulai dari sekolah dasar hingga perguruan tinggi. Selanjutnya, Sumeda (2010) menjelaskan bahwa matematika secara umum didefinisikan sebagai bidang ilmu yang mempelajari pola dari struktur, perubahan, dan ruang. Selain itu, pembelajaran matematika dapat membekali peserta didik dalam berpikir kreatif, analitis, logis, sistematis, dan kritis. Sehingga, matematika menjadi ilmu yang penting untuk dipelajari peserta didik sejak dini.

Namun, kenyataan dilapangan saat ini, kemampuan matematis siswa di Indonesia masih termasuk kategori rendah. Hal ini ditunjukkan berdasarkan penelitian yang dilakukan oleh TIMSS dan PISA pada tahun 2007 (Japa, Suarjana \& Widiana, 2017) yang memaparkan bahwa prestasi matematika siswa di Indonesia dengan sampel penelitian kelas VIII, berada pada peringkat ke-36 dari 49 negara yang ikut berpartisipasi dengan nilai rerata yang didapat 397 dibawah nilai rerata Internasional yaitu 500. Rendahnya prestasi matematika siswa tersebut, selaras dengan penelitian Ernawati et al., (2020) di salah satu sekolah Kabupaten Bandung Barat tahun pelajaran 2018/2019 yang menunjukkan bahwa ketercapaian siswa dalam mengerjakan soal matematika tergolong masih rendah. Hal tersebut, disebabkan karena siswa tidak mengetahui prosedur atau langkah-langkah yang akan digunakan untuk menyelesaikan soal dengan tepat. Kesulitan siswa dalam menyelesaikan soal matematika cenderung membuat kurangnya minat belajar tehadap pembelajaran matematika.

Berkaitan dengan minat belajar, Slameto (2010) menjelaskan bahwa minat adalah rasa lebih menyukai dan tertarik terhadap sesuatu atau aktivitas lain berdasarkan kesadaran diri sendiri. Sedangkan, Rojabiyah \& Setiawan (2015) melihat minat belajar sebagai suatu kegiatan yang dilakukan seseorang secara senang dan tetap tanpa ada yang memaksa dalam suatu proses pembelajaran. Oleh karena itu, minat siswa dalam pelajaran matematika perlu ditumbuhkan agar hasil belajar siswa dapat meningkat. Salah satu strategi menumbuhkan minat siswa dalam belajar dapat dilakukan oleh guru adalah menggunakan media pembelajaran inovatif agar siswa lebih tertarik lagi dalam belajar. Seiring berkembang pesatnya IPTEK, dewasa ini telah banyak yang memanfaatkan media pembelajaran berbasis Teknologi diantaranya adalah penggunaan software GeoGebra.

GeoGebra adalah salah satu program dinamis yang mempunyai fasilitas untuk 
memvisualisasikan atau mendemonstrasikan konsep-konsep matematika juga dapat membantu dalam mengkonstruksi konsep-konsep matematika (Syahbana, 2016). GeoGebra dikembangkan oleh Markus Hohenwarter pada tahun 2001. Selanjutnya, Hohenwarter (dalam Putri, Candiasa, \& Suweken, 2016) mendefiniskan GeoGebra sebagai software yang digunakan dalam membelajarkan matematika, khususnya pada topik geometri dan aljabar. Selain itu, GeoGebra memiliki beragam representasi dari objek matematika diantaranya Titik, vektor, garis, bentuk kerucut dan fungsi yang dapat digambarkan dan kemudian secara dinamis dapat diubah (Permatasari, Dafik, \& Fatahilah, 2016). Salah satu materi pada pelajaran matematika yang memerlukan visualisasi adalah Grafik Fungsi Kuadrat.

Berdasarkan hasil penelitian Isfan, Rahim, \& Jazuli (2018) pada 23 siswa kelas X3 SMA Negeri 1 Asera menjelaskan bahwa masih banyak siswa yang mengalami kesalahan ketika menyelesaikan soal mengenai fungsi kuadrat. Kesalahan tersebut diantaranya terletak pada kesalahan konsep, prinsip dan perhitungan. Pada kesalahan prinsip, siswa belum mampu mengilustrasikan bentuk grafik fungsi kuadrat dan nilai titik puncaknya dari nilai $\alpha$. Hal tersebut dikarenakan masih kurangnya pemahaman dasar siswa terhadap konsep fungsi kuadrat. Agar siswa lebih mudah memahami dan mengilustrasikan suatu grafik fungsi kuadrat, guru dapat memanfaatkan media pembelajaran berupa software GeoGebra. Sebagaimana pendapat yang dikatakan Widyaningrum \& Murwanintyas (2013), di dalam GeoGebra siswa mampu melihat dan mengeksplorasi grafik fungsi kuadrat serta dapat memanipulasi grafik tersebut dengan cara mengubah konstanta dan koefisien pada persamaan fungsi kuadratnya. Sehingga, hal tersebut diharapkan mampu membantu siswa memahami materi tersebut.

Penggunaan media pembelajaran berupa Software GeoGebra memiliki pengaruh positif terhadap materi Grafik Fungsi Kuadrat. Hal ini ditunjukkan oleh hasil penelitian yang dilakukan oleh Hamidah, Afidah, Setyowati, Sutini, dan Junaedi (2020) yang menjelaskan bahwa hasil belajar peserta didik menggunakan media pembelajaran GeoGebra pada materi Fungsi Kuadrat lebih baik daripada peserta didik yang tidak menggunakan GeoGebra. Selain itu, Wulandari (2019) mengemukakan bahwa penggunaan Software GeoGebra memberikan manfaat terhadap keterampilan siswa dalam menyelesaikan soal pada materi Grafik Fungsi, diantaranya memudahkan siswa memahami materi dan menganalisa lebih dalam melalui visualisasi yang lebih detail. 
Oleh karena itu, perlu dilakukan analisis lebih mendalam tentang pengaruh penggunaan GeoGebra terhadap minat belajar siswa SMP di Kabupaten Bandung Barat pada materi Grafik Fungsi Kuadrat di Kelas IX.

\section{METODE PENELITIAN}

Metode yang digunakan dalam penelitian ini adalah penelitian deskriptif, yaitu penelitian yang menghasilkan data deskriptif melalui presentase jawaban siswa yang memuat 5 indikator skala minat belajar siswa pada angket yang diberikan. Penggunaan metode deskriptif dalam penelitian ini untuk menganalisis sejauh mana minat siswa dalam pelajaran matematika pada materi Grafik Fungsi Kuadrat berbantuan Software GeoGebra.

Populasi yang digunakan adalah seluruh siswa SMP di Kabupaten Bandung Barat, sedangkan sampelnya yaitu 28 siswa kelas IX di SMP Bingkai Cendikia Cililin. Pada penelitian ini instrumen yang digunakan adalah instrumen non test, yaitu angket minat belajar yang terdiri dari 20 pernyataan dengan masing - masing 10 pernyataan positif dan 10 pernyataan negatif dengan 4 pilihan jawaban yaitu Sangat Setuju, Setuju, Tidak Setuju, dan Sangat Tidak Setuju (Lampiran 1).

Nilai rata-rata secara keseluruhan dari data yang diperoleh, digunakan sebagai sumber penarikan kesimpulan. Untuk menghitung rata-rata tersebut, digunakan rumus menurut Arikunto (2010) sebagai berikut:

$$
\bar{x}=\frac{\sum x}{n}
$$

dimana:

$\bar{x}=$ rata-rata (mean)

$\sum x=$ jumlah seluruh skor

$\mathrm{n}=$ banyaknya subjek

Analisis data yang berhubungan dengan minat belajar siswa dilakukan dengan melakukan perhitungan presentase. Formula untuk menghitung presentase minat belajar matematika siswa yaitu dengan menggunakan rumus dari Sudijono (2008) sebagai berikut:

$$
\mathrm{P}=\frac{f}{N} \times 100 \%
$$


dimana:

$\mathrm{P}=$ angka presentase

$\mathrm{f}=$ frekuensi yang muncul

$\mathrm{N}=$ jumlah frekuensi atau banyaknya individu

Presentase yang diperoleh dari masing-masing indikator, kemudian ditafsirkan pada kategori sebagaimana dikemukan oleh Ali \& Asrori (2005), yang dapat dilihat pada Tabel 1.

Tabel 1. Kriteria Penilaian Minat Belajar Siswa Matematika

\begin{tabular}{cl}
\hline Kelompok Persentase & Hasil Penilaian \\
\hline $75,01-100,00$ & Sangat Baik \\
$50,01-75,00$ & Baik \\
$25,01-50,00$ & Cukup Baik \\
$0,01-25,00$ & Kurang Baik \\
\hline
\end{tabular}

\section{HASIL DAN PEMBAHASAN}

Hasil presentase minat siswa dalam pelajaran matematika pada materi Grafik Fungsi Kuadrat berbantuan Software GeoGebra yang melalui instrumen non test atau angket yang memuat 5 indikator skala sikap minat belajar matematik siswa. Hasil presentase ini dicantumkan dalam Tabel 2.

Tabel 2. Presentase Skala Sikap Minat Belajar Siswa

\begin{tabular}{|c|c|c|c|c|c|c|}
\hline \multirow{2}{*}{ No } & \multirow{2}{*}{ Indikator } & \multicolumn{4}{|c|}{ Respons (\%) } & \multirow{2}{*}{ Keterangan } \\
\hline & & SS & $\mathbf{S}$ & TS & STS & \\
\hline 1. & Perasaan Senang & 25 & 70 & 5 & 0 & Sangat baik \\
\hline 2. & Ketertarikan Siswa & 16 & 84 & 0 & 0 & Sangat baik \\
\hline 3. & Keterlibatan Siswa & 20 & 65 & 10 & 5 & Sangat baik \\
\hline & $\begin{array}{l}\text { Rajin belajar dan mengerjakan tugas } \\
\text { matematika }\end{array}$ & 18 & 56 & 20 & 6 & Baik \\
\hline 5. & $\begin{array}{l}\text { Tekun dan disiplin dalam belajar dan } \\
\text { memiliki jadwal belajar }\end{array}$ & 19 & 60 & 19 & 2 & Sangat baik \\
\hline
\end{tabular}


Proses pembelajaran matematika pada materi Grafik Fungsi Kuadrat dilakukan dengan cara mengkolaborasikan sajian materi dengan visualisasi Grafik Fungsi Kuadrat melalui Software GeoGebra. Sebelumnya siswa mempelajari cara membuat grafik fungsi kuadrat secara manual, kemudian mengaplikasikan ilmu yang didapat melalui Software GeoGebra. Lebih lanjut, untuk mengetahui sejauh mana minat belajar siswa terhadap penggunaan Software GeoGebra pada materi Grafik Fungsi Kuadrat, siswa mengisi angket skala minat belajar setelah proses pembelajaran selesai dilakukan.

Hasil dari jawaban 28 orang siswa yang menjawab Sangat Setuju, Setuju, Tidak Setuju, dan Sangat Tidak Setuju pada setiap indikator skala sikap minat belajar siswa disajikankan dalam bentuk Diagram.

1. Analisis respon siswa pada indikator perasaan senang menggunakan Software GeoGebra

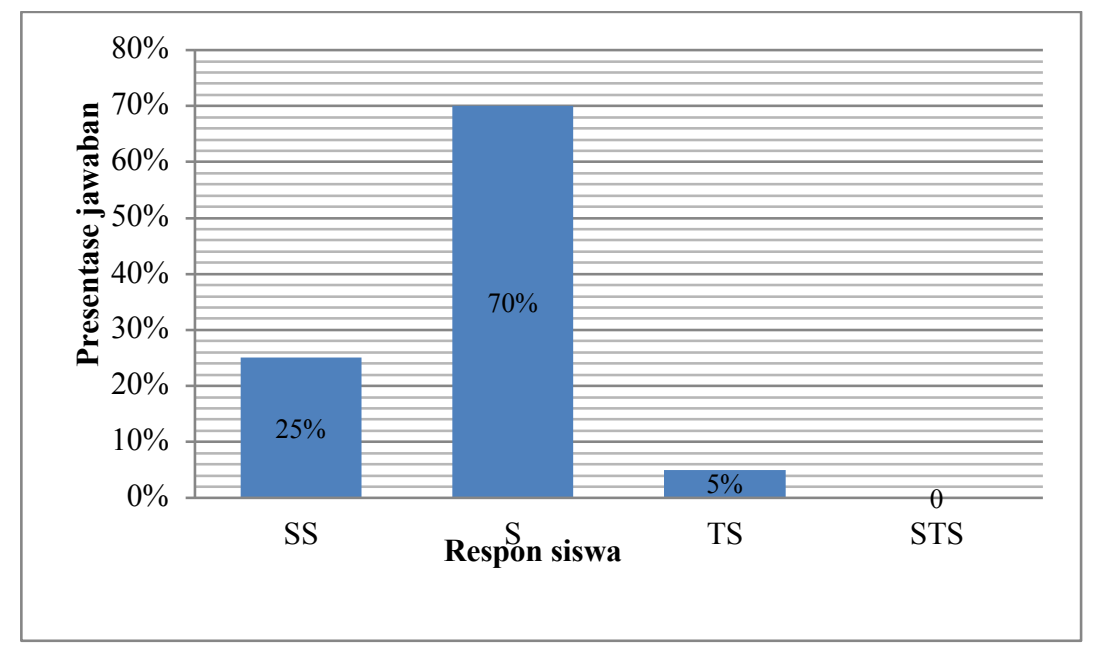

Gambar 1. Presentase pada indikator perasaan senang

Hasil analisis deskriptif dari Gambar 1, menunjukkan bahwa terdapat 25\% siswa berpendapat sangat setuju ketika guru menyampaikan materi menggunakan software GeoGebra, begitupun 70\% siswa lainnya menyatakan setuju sehingga terdapat perasaan senang ketika pembelajaran matematika siswa dibantu dengan software GeoGebra. Sedangkan 5\% lainnya tidak merasa tidak senang, karena kurang mengerti terhadap materi yang disampaikan guru. Pada indikator perasaan senang ini, minat siswa dalam pelajaran matematika dapat dikategorikan sangat baik. 
Journal of Honai Math, Vol. 3, No. 1, pp. 27-40, April 2020

Khodijah \& Setiawan, Analisis Minat Belajar Matematika Siswa SMP Kelas IX pada Materi Grafik

Fungsi Kuadrat berbantuan Software Geogebra

2. Analisis respon siswa pada indikator ketertarikan siswa pada saat pembelajaran menggunakan Software GeoGebra

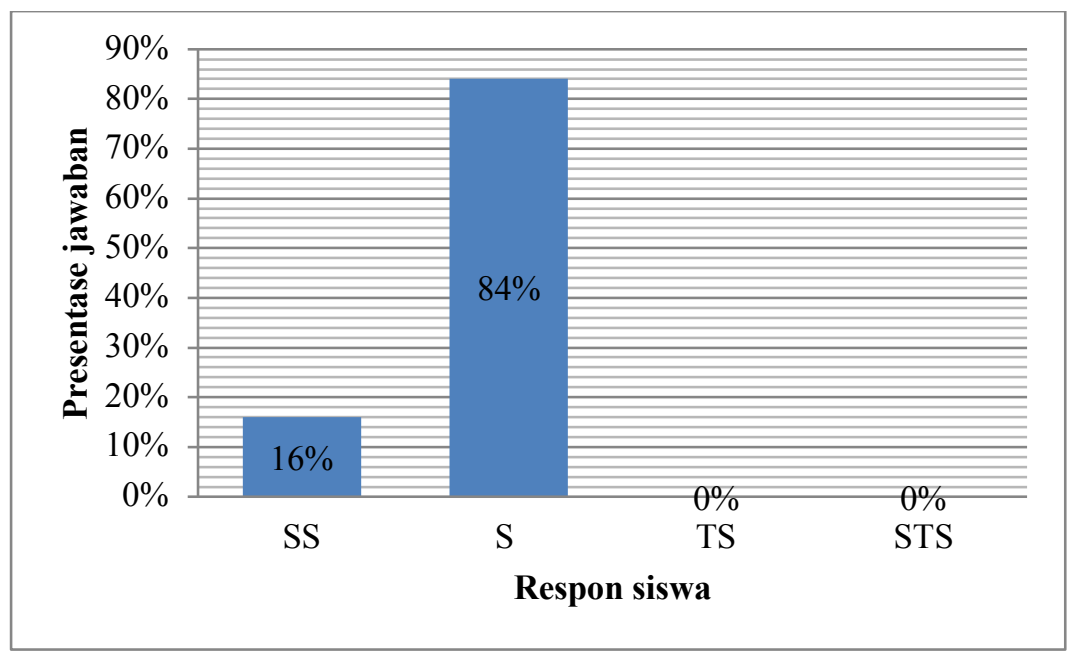

Gambar 2. Presentase pada indikator ketertarikan siswa

Dari respon siswa yang terlihat pada Gambar 2, dapat dianalisis bahwa terdapat sebanyak $16 \%$ siswa berpendapat sangat setuju dalam menyatakan tertarik dalam pelajaran matematika pada materi Grafik Fungsi Kuadrat yang menggunakan Software GeoGebra, dan $84 \%$ siswa lainnya pun berpendapat setuju karena mereka merasa sangat tertarik dalam mengikuti proses pembelajaran, sehingga tumbuh perasaan semangat. Presentase pada indikator ini dapat disimpulkan bahwa ketertarikan siswa pada software GeoGebra ketika proses pembelajaran dikategorikan sangat baik.

3. Analisis respon siswa pada indikator keterlibatan siswa pada pembelajaran menggunakan Software GeoGebra

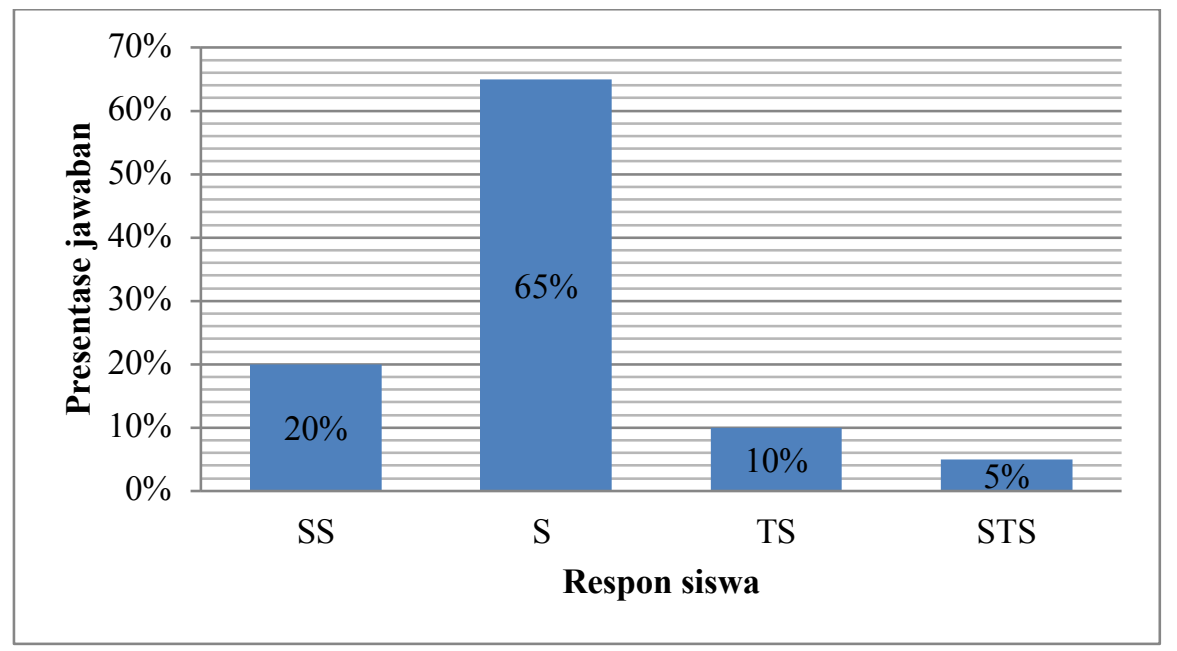

Gambar 3. Presentase pada indikator keterlibatan siswa 
Berdasarkan hasil data pada Gambar 3, sebanyak 20\% siswa berpendapat sangat setuju dalam keterlibatannya pada pembelajaran matematika yang dibantu dengan adanya software GeoGebra. Kemudian, sebanyak 65\% siswa menyatakan setuju pada hal tersebut. Namun, ada $10 \%$ siswa yang berpendapat tidak setuju dalam keterlibatannya pada pelajaran matematika. Hal itu disebabkan karena sebagian siswa yang tidak percaya diri ketika mengerjakan soal matematika didepan kelas dan mereka malas membuat catatan matematika yang sudah diajarkan. Pernyataan tersebut diperkuat oleh pendapat siswa yang mengatakan sangat tidak setuju dalam keterlibatannya selama belajar matematika sebanyak 5\% siswa. Pada indikator keterlibatan siswa ini, minat siswa dalam pelajaran matematika berbantuan Software GeoGebra dapat dikategorikan cukup baik.

4. Analisis respon siswa pada indikator rajin dalam belajar dan rajin mengerjakan tugas matematika saat proses pembelajaran menggunakan Software GeoGebra

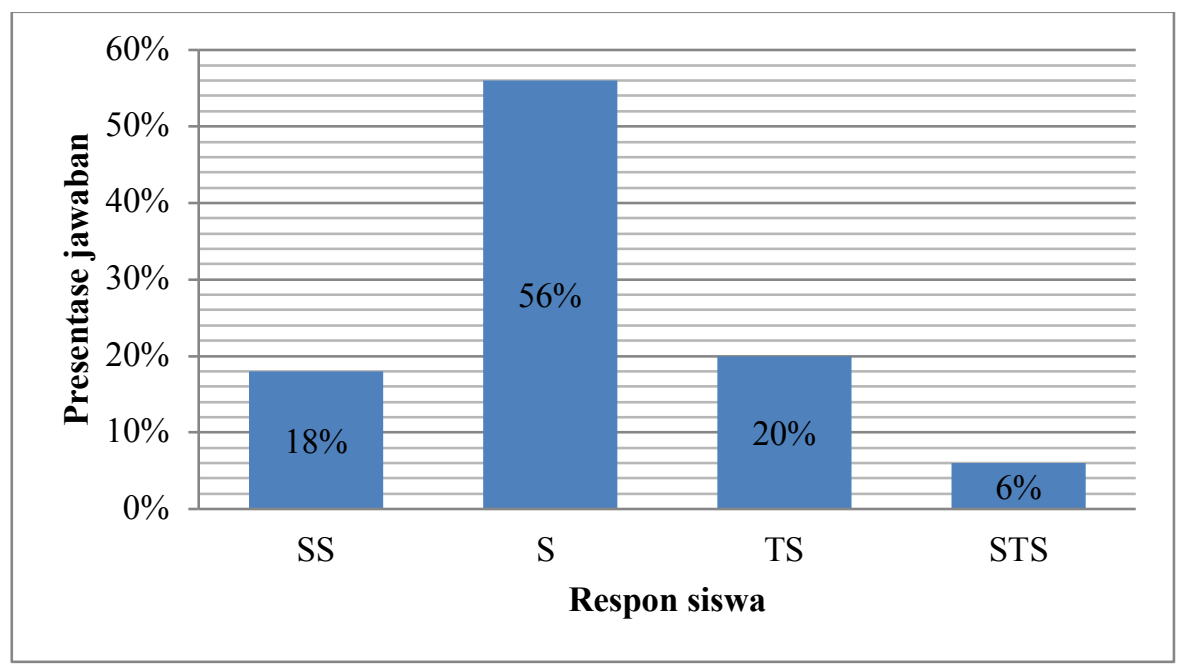

Gambar 4. Presentase pada indikator rajin belajar dan rajin mengerjakan tugas matematika

Hasil analisis deskriptif presentase respon siswa pada Gambar 4, menyatakan bahwa $18 \%$ siswa berpendapat sangat setuju pada pernyataan rajin dalam belajar dan rajin mengerjakan tugas matematika, hal tersebut diperkuat juga oleh pendapat siswa lainnya sebanyak 56\% yang menyatakan setuju. Tetapi, ada juga yang mengatakan tidak setuju dalam pernyataan tersebut sebanyak $20 \%$ siswa. Hal tersebut dikarenakan banyak siswa yang menjadi malas belajar matematika ketika mengerjakan soal yang rumit. Begitupun $6 \%$ siswa lainnya berpendapat sangat tidak setuju dalam pernyataan tersebut. 
Pada presentase indikator rajin dalam belajar dan rajin mengerjakan tugas matematika dapat dikategorikan minat belajar siswa tergolong baik.

5. Analisis respon siswa pada indikator tekun dan disiplin dalam belajar dan memiliki jadwal belajar saat proses pembelajaran menggunakan Software GeoGebra

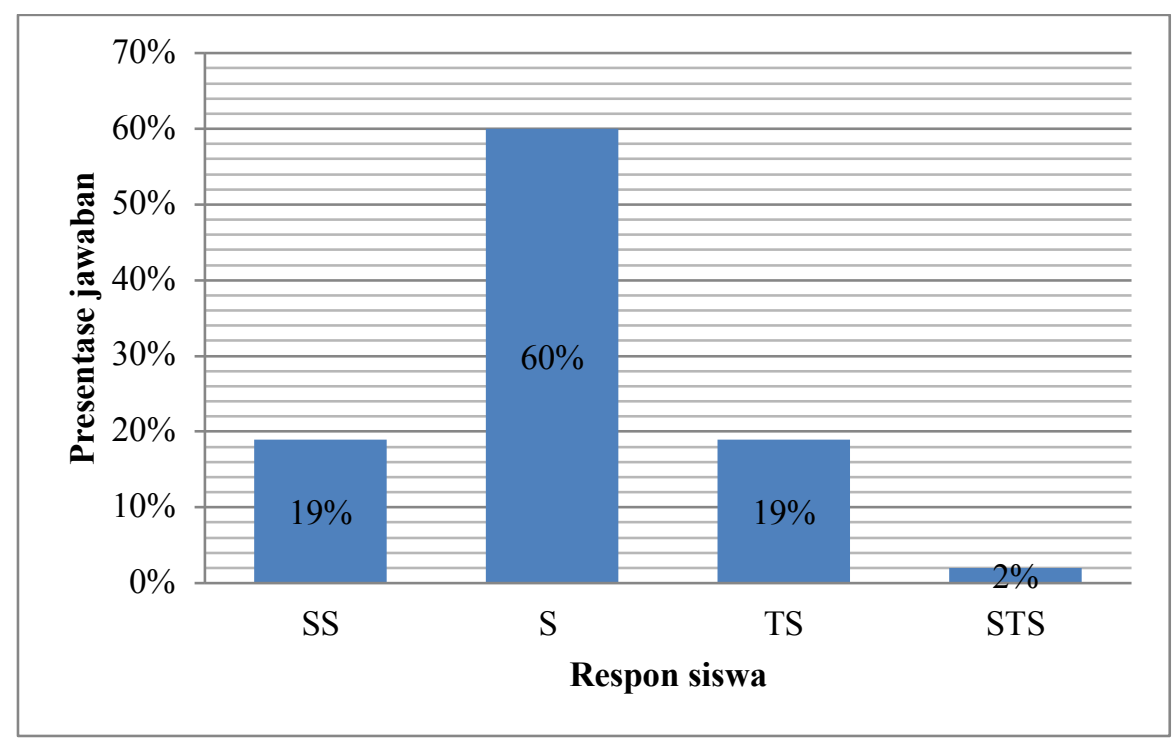

Gambar 5. Presentase pada indikator tekun dan disiplin dalam belajar dan memiliki

$$
\text { jadwal belajar }
$$

Hasil analisis deskriptif pada Gambar 5, dapat dilihat terdapat 19\% siswa berpendapat sangat setuju dalam pernyataan tekun dan disiplin dalam belajar dan memiliki jadwal belajar. Kemudian, 60\% siswa lainnya berpendapat setuju pada pernyataan tersebut. Selain itu, ada beberapa siswa yang berpendapat tidak setuju juga dalam pernyataan tersebut sebanyak 19\%. Hal itu, dapat terjadi karena sebagian siswa menjadi malas belajar matematika ketika materinya sulit untuk dipahami dan juga siswa belajar matematika hanya karena materi yang mereka pelajari dianggap mudah. Hal tersebut diperkuat juga oleh pendapat siswa lainnya sebesar $2 \%$ yang mengatakan sangat tidak setuju dalam pernyataan tekun dan disiplin dalam belajar dan memiliki jadwal belajar. Namun, presentase pada indikator ini minat belajar siswa dapat dikategorikan baik.

Berdasarkan analisis deskriptif respon siswa diatas, menunjukkan bahwa penggunaan Software GeoGebra pada materi Grafik Fungsi Kuadrat memiliki pengaruh positif terhadap minat belajar siswa. Hal tersebut ditunjukkan melalui respon siswa yang merasa senang dan tertarik dengan adanya media tersebut sehingga menyebabkan siswa 
terlibat langsung dalam proses pembelajaran, rajin mengerjakan tugas, dan tekun dalam belajar. Adanya minat belajar siswa terhadap pembelajaran matematika yang menggunakan Software GeoGebra ini sejalan dengan hasil penelitian Rahmawati, Bungsu, Islamiah, \& Setiawan (2019). Dalam penelitiannya, mereka menyimpulkan bahwa terdapat pengaruh yang positif terhadap minat belajar siswa pada pembelajaran matematika yang menggunakan Software GeoGebra, yaitu timbulnya rasa ingin tahu yang lebih dan perasaan senang sehingga mendorong siswa berperan aktif dan terlibat langsung selama proses pembelajaran. Selain itu, Andarwati \& Hernawati (2013) menunjukkan bahwa minat siswa dalam menggunakan LKS berbantuan GeoGebra berada dalam kategori baik. Di sisi lain, Ariawan (2015) menyatakan bahwa pemanfaatan Software GeoGebra membuat proses pembelajaran menjadi lebih efektif. Hal itu terlihat dari pemanfaatan waktu yang digunakan menjadi lebih singkat, aktivitas guru lebih sedikit dan lebih ringan serta hasil yang diperoleh melalui Software GeoGebra jauh lebih tepat, menarik dan akurat.

\section{SIMPULAN}

Penggunaan software GeoGebra pada materi Grafik Fungsi Kuadrat di SMP Bingkai Cendikia Cililin berpengaruh positif terhadap minat siswa kelas IX pada pelajaran matematika. Banyak siswa yang merasa tertarik dan senang selama pelajaran berlangsung, sehingga mereka lebih fokus, semangat, serta minat belajar matematika nya tumbuh. Hal tersebut terlihat dari presentase rata-rata jawaban siswa yang berpendapat sangat setuju pada pernyataan positif sebanyak 49\%, kemudian pada respon setuju menghasilkan rata-rata sebesar $67 \%$, untuk respon tidak setuju hanya sebanyak $10,8 \%$, sedangkan untuk respon sangat tidak setuju menghasilkan rata-rata sebesar $6,5 \%$.

\section{DAFTAR PUSTAKA}

Ali, M., \& Asrori, M. (2005). Psikologi Remaja Perkembangan Peserta Didik. Jakarta: Bumi Aksara.

Andarwati, D., \& Hernawati, K. (2013). Pengembangan Lembar Kegiatan Siswa (LKS) Berbasis Pendekatan Penemuan Terbimbing Berbantuan Geogebra Untuk Membelajarkan Topik Trigonometri pada Sisa Kelas X SMA. Prosiding Seminar 
Nasional Matematika dan Pendidikan Matematika, Yogyakarta, 978-979.

Ariawan, B. (2015). Menyelesaikan Permasalahan Program Linier Menggunakan

Geogebra. Malang: Seminar Nasional Teknologi Pendidikan UM.

Arikunto, S. (2010). Prosedur Penelitian Suatu Pendekatan Praktik. Jakarta: Rineka Cipta.

Ernawati et al. (2020). Analisis Kesalahan Siswa Kelas V SD Berdasarkan Prosedur Newman dalam Menyelesaikan Soal Matematika Operasi Bilangan Bulat. SJME (Supremum Journal of Mathematics Education), 4(1), 13-23.

Hamidah, N., Afidah, I. N., Setyowati, L. W., Sutini, S., \& Junaedi, J. (2020). Pengaruh Media Pembelajaran Geogebra Pada Materi Fungsi Kuadrat Terhadap Motivasi dan Hasil Belajar Peserta Didik. Journal of Education and Learning Mathematics Research (JELMaR), 1(1), 15-24.

Isfan; Rahim, Utu; \& Jazuli, L. O. (2018). Analisis Kesalahan dalam Menyelesaikan Soal-soal Fungsi Kuadrat pada Siswa Kelas X3 SMA Negeri 1 Asera. Jurnal Pendidikan Matematika, 6(1), 43-56.

Japa, S. \& W. (2017). Media Geogebra dalam Pembelajaran Matematika. International Journal of Natural Science and Engineering, 1, 40-47.

Permatasari, P. A., Dafik, \& Fatahilah, A. (2016). Pengembangan Media Pembelajaran Matematika Interaktif Schoology Berbantuan Software Geogebra Materi Transformasi Geometri Kelas XI. Kadikma, 7(1), 66-75.

Putri, N. . K., Candiasa, I. M., \& Suweken, G. (2016). Pengembangan Media Pembelajaran Transformasi Berbasis Geogebra. Jurnal Wahana Matematika Dan Sains, 10(2), 25-35.

Rahmawati, N. S., Bungsu, T. K., Islamiah, I. D., \& Setiawan, W. (2019). Analisis Minat Belajar Siswa MA Al-Mubarok Melalui Pendekatan Saintifik Berbantuan Aplikasi Geogebra pada Materi Statistika Dasar. Journal on Education, 1(3), 386-395.

Rojabiyah, A. B., \& Setiawan, W. (2015). Analisis Minat Belajar Siswa MTs Kelas VII dalam Pembelajaran Matematika Materi Aljabar Berdasarkan Gender. Journal on Education, 1(2), 458-464.

Slameto. (2010). Belajar dan Faktor-faktor yang Mempengaruhinya. Jakarta: Rineka Cipta.

Sudijono, A. (2008). Pengantar Evaluasi Pendidikan. Jakarta: Raja Grafindo Persada. 
Journal of Honai Math, Vol. 3, No. 1, pp. 27-40, April 2020

Khodijah \& Setiawan, Analisis Minat Belajar Matematika Siswa SMP Kelas IX pada Materi Grafik Fungsi Kuadrat berbantuan Software Geogebra

Sumeda. (2010). Pengantar Filsafat Matematika. Surakarta: UNS Press.

Syahbana, A. (2016). Belajar Menguasai GeoGebra (Program Aplikasi Pembelajaran Matematika). Palembang: NoerFikri Offset.

Widyaningrum, Y. T., \& Murwanintyas, C. E. (2013). Pengaruh Media Pembelajaran Geogebra Terhadap Motivasi dan Hasil Belajar Siswa pada Materi Grafik Fungsi Kuadrat di Kelas X SMA Negeri 2 Yogyakarta Tahun Pelajaran 2012/2013, 978979.

Wulandari, D. A. (2019). Pemanfaatan Geogebra dalam Pembelajaran Grafik Fungsi. Prosiding Seminar Nasional Pendidikan Program Pascasarjana Universitas PGRI Palembang, Palembang, 154-159. 
Lampiran 1. Butir Instrumen Skala Sikap Minat Belajar Siswa

\begin{tabular}{|c|l|}
\hline No & \multicolumn{1}{|c|}{ Pernyataan } \\
\hline A. & Indikator: Perasaan senang \\
\hline 1. & $\begin{array}{l}\text { Saya senang belajar matematika ketika guru menjelaskan menggunakan aplikasi } \\
\text { GeoGebra. }(+)\end{array}$ \\
\hline 2. & $\begin{array}{l}\text { Saya merasa kurang senang ketika belajar matematika menggunakan Software } \\
\text { GeoGebra. }(-)\end{array}$ \\
\hline 3. & $\begin{array}{l}\text { Saya jadi lebih memahami materi matematika ketika belajar menggunakan } \\
\text { Software GeoGebra. }(+)\end{array}$ \\
\hline 4. & $\begin{array}{l}\text { Saya kurang mengerti terhadap materi yang diajarkan menggunakan Software } \\
\text { GeoGebra (-) }\end{array}$ \\
\hline B. & Indikator: Ketertarikan Siswa \\
\hline 5. & $\begin{array}{l}\text { Saya bersemangat mengikuti pelajaran matematika menggunakan Software } \\
\text { GeoGebra. }(+)\end{array}$ \\
\hline 6. & $\begin{array}{l}\text { Pembelajaran matematika menggunakan Software GeoGebra membuat saya } \\
\text { bosan belajar (-) }\end{array}$ \\
\hline 7. & $\begin{array}{l}\text { Pembelajaran matematika menggunakan Software GeoGebra } \text { membuat saya } \\
\text { kurang fokus pada materi yang dijelaskan oleh guru (-) }\end{array}$ \\
\hline 8. & $\begin{array}{l}\text { Pembelajaran matematika menggunakan Software GeoGebra } \text { membuat saya } \\
\text { lebih tertarik untuk mengikuti pembelajaran (+) }\end{array}$ \\
\hline C. & Indikator : Keterlibatan Siswa \\
\hline 9 & Selama pembelajaran matematika saya berani mengemukakan pendapat (+) \\
\hline 10 & Saya tidak percaya diri ketika disuruh mengerjakan soal di depan kelas (-) \\
\hline 11 & Saya malas membuat catatan matematika yang sudah diajarkan (-) \\
\hline 12 & $\begin{array}{l}\text { Saya merasa tertantang untuk mengerjakan soal }- \text { soal matematika yang tidak } \\
\text { rutin (+) }\end{array}$ \\
\hline D. & Indikator: rajin belajar dan rajin mengerjakan tugas matematika \\
\hline 13 & Saya merasa malas mengerjakan tugas matematika yang rumit (-) \\
\hline 14 & Saya memilih soal latihan matematika yang sederhana (-) \\
\hline 15 & Saya memilih sendiri tugas matematika yang menurut saya lebih menantang $(+)$ \\
\hline 16 & Saya semangat mengerjakan tugas matematika (+) \\
\hline E. & Indikator: Tekun dan disiplin dalam belajar dan memiliki jadwal belajar \\
\hline 17 & $\begin{array}{l}\text { Saya berusaha menyelesaikan soal matematika yang sulit meski perlu waktu } \\
\text { lama (+) }\end{array}$ \\
\hline 18 & Saya berusaha rutin belajar matematika sesuai jadwal yang sudah saya susun $(+)$ \\
\hline 19 & $\begin{array}{l}\text { Saya belajar matematika hanya ketika materi yang dipelajari menurut saya } \\
\text { mudah (-) }\end{array}$ \\
\hline 20 & Saya malas belajar matematika ketika materinya sulit untuk saya pahami $(-)$ \\
\hline & \\
\hline
\end{tabular}


Journal of Honai Math, Vol. 3, No. 1, pp. 27-40, April 2020

Khodijah \& Setiawan, Analisis Minat Belajar Matematika Siswa SMP Kelas IX pada Materi Grafik Fungsi Kuadrat berbantuan Software Geogebra 